\title{
Reduktion af oliebaseret energi - og fokus på vedvarende energi
}

Af geolog Nick Svendsen

Danmark bruger for mange penge på at reducere $\mathrm{CO}_{2}$-udslip og forsøger at dreje debatten væk fra problemet om manglen på olie. Der bør fokuseres mere på energisparende projekter og alternativ energi og gøres en større indsats inden for området, mener debattøren.

Opvarmningen af Jordens klima bliver til tider diskuteret heftigt i pressen også her i GeologiskNyt. Jeg har med glæde læst Poul Ancher Larsens indlæg i klimadebatten i Weekendavisen 1. -7. april. Jeg har som ham en skeptisk holdning til Kyoto-aftalen og er skeptisk overfor, om $\mathrm{CO}_{2}$-afgifter og hele den administration, det forårsager, er løsningen på Jordens problemer.

P.A. Larsens pointe er, at vi overhovedet ikke ved, om alle de penge, der bruges på at reducere udslippet af drivhusgasser, hjælper. For ham er det det samme som at betale aflad.

\section{Klimadebatten}

Jeg har med forundring læst nogle af de forslag, der er fremlagt for at reducere $\mathrm{CO}_{2}-$ udslippet ved at injicere den producerede $\mathrm{CO}_{2} \mathrm{i}$ reservoirbjergarter dybt nede $\mathrm{i}$ jorden. Forslagene kan læses på GEUS's hjemmeside.

Grundlaget for klimadebatten er behand- let i februarnummeret af GeologiskNyt af A.M.K. Jørgensen. En i øvrigt glimrende artikel, som nøgternt fremlægger grundlaget for klimamodellerne. Hun er medforfatter til bogen "Den Globale Opvarmning", hvor hele emnet også glimrende bliver behandlet.

Der er ingen tvivl om, at disse klimamodeller er baseret på sunde fysiske principper og bliver stadig mere sikre.

Det er næppe heller nogen tvivl om, at $\mathrm{CO}_{2}$ og andre drivhusgasser vil opvarme klodens klima, men hvornår!

Afhængigt af hvilken fremskrivning man bruger, vil temperaturstigningen være mellem 2 og 5 grader, når vi når ind i det næste århundrede. Det vil dog tage adskillige årtier før, vi med sikkerhed kan afgøre, hvor hurtigt temperaturstigningen vil være. Der er i bogen "Den Globale Opvarmning" en lang liste over tiltag og projekter, der for tiden er $i$ gang i Danmark. Det er mange penge, der bruges på klimarelaterede projekter ( 50 milliarder kroner i 2000). Det er derfor vigtigt, at disse penge bruges fornuftigt. Mange af projekterne inkluderer heldigvis fokus på energibesparelser.

En væsentlig del af $\mathrm{CO}_{2}$-udslippet kommer fra fossile brændstoffer under fremstilling af energi. Man har i Europa forsøgt at reducere energiforbruget og er nået langt. Desværre ser vi ikke samme tendens i USA og de nye "tiger-økonomier" i Asien så som Kina.

Energiforbruget er kraftigt forøget på det sidste, hvilket har forårsaget en gevaldig stigning i olieprisen. Med det stigende for- brug vil vores reserver af olie og gas være forbrugt i det næste århundrede. Og så har vi jo løst $\mathrm{CO}_{2}$-problemet.

Her er vi så ved kernen i min skepsis. Klimadebatten skjuler eller drejer debatten væk fra et mindst lige så alvorligt problem, nemlig at vi er ved at løbe tør for kulbrintebaseret energi. Manglen på olie har mindst lige så mange samfundsmæssige problemer som "Global Warming". For mig er kodeordet ikke "Global Warming" men "Energy Conservation".

Ressourcerne skal bruges anderledes Vi bør derfor bruge vores ressourcer til at reducere den oliebaserede energi og forskning $i$ alternative energiformer frem for tvivlsomme og dyre tiltag til at reducere $\mathrm{CO}_{2}$-udledningen. GEUS leverer et udmærket eksempel på deres hjemmeside. Der bliver brugt adskillelige millioner kroner på projekter, hvor man vil undersøge muligheden for at deponere $\mathrm{CO}_{2}$ fra kraftværker i undergrunden. Andre undersøger muligheden for at opsamle $\mathrm{CO}_{2}$ fra danske kraftværker ved at injicere gassen ned i Nordsøens oliereservoirer for at øge den mængde af olie, der kan produceres fra felterne. I princippet en udmærket idé, men hvad koster det i ressourcer i form af rørledninger og energi til at komprimere gassen? Sådan et projekt flytter forureningen, men gør ikke noget ved den. Tarjei Haaland fra Greenpeace leverer et fornuftigt indlæg imod ideerne, idet han siger, "Nej, det vil blive en sovepude i forhold til at gøre det rigtige i form af et seriøst og 
målrettet arbejde med at skabe bæredygtige løsninger med øget brug af vedvarende energikilder og omfattende energibesparelser".

Jeg er helt enig, og GEUS har derved leveret et fornemt eksempel på, at $\mathrm{CO}_{2}$-debatten i nogen grad er på vej ud i en blindgyde.

Mange af de penge, som i Danmark og Europa investeres $\mathrm{i} \mathrm{CO}_{2}$-reducerende tiltag, kan bruges meget bedre andre steder i verden.

\section{Energispild}

Det energispild, man ser i USA og i Asien, som forårsager den væsentligste del af $\mathrm{CO}_{2}-$ udslippet, bør reduceres. Ikke på grund af $\mathrm{CO}_{2}$-udslippet, men fordi der skal spares på energien. USA forbruger ca. $25 \%$ af den olie, der produceres i Verden af en befolkning, der udgør ca. $7 \%$ af verdens befolkning. Forbruget er ca. 7 milliarder tønder olie, hvoraf ca. $2 / 3$ bruges til energi for transport. USA kunne let reducere forbruget af energi til transportsektoren med $10 \%$ eller mere ved at udskifte bilparken med biler, der kører længere på en liter benzin. Med dagens oliepriser kunne landet spare 23 til 25 milliarder dollars, for hver $10 \%$ der spares på transport energi. Penge, der vil reducere landets importunderskud og formodentlig også opfylde landets $\mathrm{CO}_{2}$-reducerende kvota, hvis det var af interesse. USA overbevises ikke ved hjælp af Kyoto-aftalen til at reducere $\mathrm{CO}_{2}$-udslippet, men ved hjælp af økonomiske argumenter, fokus skal være på besparelser frem for udgifter.

Kina, en anden stor energisluger, skal overbevises om, at den energipolitik, som Europa fører, også vil være sund for Kina. Lige nu ligger landets forbrug omkring 2 milliarder tønder olie, og det forventes at stige til 10 milliarder tønder 2025.

Disse lande kan spare på energien meget lettere end i Europa og ved meget færre omkostninger.

Så i stedet for at Danmark bruger penge og ressourcer på at reducere $\mathrm{CO}_{2}$-udslippet yderligere, kunne man jo give pengene til projekter, som vil have en meget større effekt $i$ andre lande.

$\mathrm{CO}_{2}$-kvotesystemet giver i princippet muligheden herfor, men i mine øjne giver kontrollen med $\mathrm{CO}_{2}$-kvoterne kun mere bureaukrati og sikrer ikke, at pengene bliver brugt rigtigt. Men det er måske det, administrationen i EU gerne vil?

\section{Fremtidens energi}

Udover naturligvis at holde energiforbruget $i$ Danmark i ave, kunne man jo tænke fremadrettet. Der tales for eksempel om, at brint bliver fremtidens energi, og som ved forbrænding ikke udleder $\mathrm{CO}_{2}$. Der snakkes yderligere om, at et hydroelektrisk anlæg $\mathrm{i}$ Grønland ville kunne generere brint en gang i fremtiden. Hvorfor ikke nu? Grønland og Færøerne er begge små og lukkede samfund, som kunne omstilles til hydroelektrisk energi og brint. Et pilotanlæg i Grønland, som fremstiller brint til de Grønlandske og Færøske biler, ville vise vejen fremad. Anlægget kunne finansieres af Staten og af danske energiselskaber og derved ikke belaste skatteyderne mere end højst nødvendigt.

Selskaberne ville så stå med ekspertisen den dag, hvor der er behov for brintenergi i resten af Verden. Man kunne også omstille et af kulkraft-elværkerne i Danmark til brintenergi. Anlægget ville samtidig hjælpe Danmark med at reducere $\mathrm{CO}_{2}$-udledningen og spare på den fossile energi. Sådan et projekt indebærer en stor teknisk udfordring.

Teknologisk Institut har specialiseret sig $i$ forskning af brintenergi og er i gang med at løse de mange tekniske spørgsmål, der er i forbindelse med brintenergi - lad os støtte dem frem for tvivlsomme projekter som fremlagt på GEUS's hjemmeside.

Så mit personlige forslag er: Opgiv $\mathrm{CO}_{2}$ kvoteordningen og koncentrer den danske indsats på energisparende projekter og alternativ energi. Og så skal Udenrigsministeren på arbejde i USA og Kina.

Jeg vil slutte af med at citerer fra Journal of Petroleum Technology's majnummer, hvor Tim Wyman plæderer for "Energy Conservation", og som han siger: "A barrel oil saved is a barrel oil discovered".

\section{Litteratur:}

Litt. National Geographic 2004 no. 4. Den Globale opvarmning, bekompelse og tilpasning Af A.M.K.Jørgensen, K. Halsnoes og J. Fenger, Gads Forlag

\section{Kort nyt}

\section{Deep Impact på kometjagt}

NASA's "Deep Impact" rumfartøj observerede den 22. juni et kraftigt udbrud af is og andre partikler fra kometen Temple 1. Udbruddet blev målt som en dramatisk forøgelse af lysstyrken og var over seks gange kraftigere end et lignende udbrud den 14. juni. Spektrometre på Deep Impact detekterede dobbelt så meget vanddamp i kometens koma, mens mængden af andre gasser inklusive kuldioxid voksede endnu mere. "To udbrud inden for en uge giver anledning til at tro, at sådanne udbrud er ret almindelige", udtaler Jessica Sunshine fra gruppen bag Deep Impact, og fortsætter: "Vi må nu betragte dem som en betydelig del af den forandring, der sker på kometer, når de opvarmes på vej mod Solen".
Deep Impact er på vej mod et planlagt møde med kometen den 4. juli. Deep Impact består af et overflyvningsfartøj og et probefartøj. Ved mødet sendes probefartøjet fra overflyvningsfartøjet med 36.000 km i timen dybt ned i overfladen på kometen. Det knapt $400 \mathrm{~kg}$ tunge probefartøj forventes at skabe et krater på flere hundrede meter og derved blotlægge kometens uberørte indre. Overflyvningsfartøjet vil bruge sine kameraer og sit infrarøde spektrometer til at opsamle og sende billeder og spektre af begivenheden ned til Jorden. Hubble teleskopet, Spitzer Space teleskopet, Chandra Røntgen Observatoriet og store og små teleskoper på Jorden vil også observere sammenstødet og dets følger. www.nasa.gov/deepimpact/JT 